\title{
Kinetic modeling of heavy metal sorption by vinyl pyridine based copolymer
}

\author{
Danijela D. Maksin ${ }^{1}$, Slađana O. Kljajević ${ }^{2}$, Maja B. Đolić ${ }^{1}$, Jelena P. Marković ${ }^{1}$, Bojana M. Ekmeščić ${ }^{2}$, \\ Antonije E. Onjia ${ }^{1}$, Aleksandra B. Nastasović ${ }^{2}$ \\ ${ }^{1}$ University of Belgrade, Vinča Institute of Nuclear Sciences, Belgrade, Serbia \\ ${ }^{2}$ University of Belgrade, ICTM - Center for Chemistry, Polymer Department, Belgrade, Serbia
}

\begin{abstract}
Commercial macroporous poly(4-vinylpyridine-co-divinylbenzene) [P4VPD], known as Reillex-425, was characterized by mercury porosimetry, nitrogen physisorption, Fourier transformed infrared (FTIR) spectroscopy and elemental analysis. Sorption rates of P4VPD for $\mathrm{Cu}(\mathrm{II}), \mathrm{Co}(\mathrm{II})$ and $\mathrm{Cr}(\mathrm{VI})$ ions were determined in static non-competitive experiments, at room temperature $(298 \mathrm{~K})$. Rapid sorption was observed, especially for $\mathrm{Co}(\mathrm{II})$, with half time, $t_{1 / 2}$, of $1.5 \mathrm{~min}$ and high experimental maximal capacity, $Q_{\max }$, of $3.08 \mathrm{mmol} \mathrm{g}^{-1}$. Four kinetic models (pseudo-first and pseudo-second order model, intraparticle diffusion and Boyd model) were used for analyzing metal sorption by P4VPD. Metal ions sorption is well represented by the pseudo-second-order model, with definite influence of pore and film diffusion on sorption rates.
\end{abstract}

Keywords: poly(4-vinylpyridine-co-divinylbenzene) macroporous copolymer; $\mathrm{CU}(\mathrm{II}), \mathrm{Co}(\mathrm{II})$ and $\mathrm{Cr}(\mathrm{VI})$ ions sorption; kinetic models.

SCIENTIFIC PAPER

UDC 678.7/.8:546.3:544.723

Hem. Ind. 66 (6) 795-804 (2012)

doi: 10.2298/HEMIND121002112M

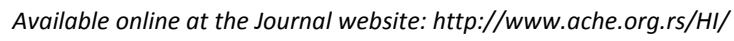

Kinetic modeling of metal sorption is extremely important since the effectiveness of the sorption process for pollutant removal from aqueous solutions strongly depends on the sorption dynamics. Predicting the rate at which sorption takes place in a given system is one of the crucial factors in sorption system design [1]. Modeling of sorption kinetics can be carried out by employing chemical reaction-based and particle diffusion-based models. Among the most commonly encountered expressions in pollutant sorption studies are Lagregen's pseudo-first-order and Ho's pseudo-second-order [2]. However, these and other chemical reaction-based kinetic models do not consider the importance of particle diffusion processes in metal sorption by porous materials [3]. Therefore, it is necessary to include diffusion-based kinetic modeling in order to elucidate the role of diffusion processes, such as film and intraparticle diffusion.

Heavy metal pollution is an environmental problem of worldwide concern. Adsorption is an efficient and cost-effective process for treatment of water and industrial effluents. Numerous inorganic and organic adsorbents can be applied for heavy metal removal from wastewaters; polymeric chelating and ion-exchange resins are widely utilized for these purposes.

Correspondence: A.B. Nastasović, University of Belgrade, ICTM -Center for Chemistry, Polymer Department, Njegoševa 12, 11000 Belgrade, Serbia.

E-mail: anastaso@chem.bg.ac.rs; anastasovic@yahoo.com

Paper received: 2 October, 2012

Paper accepted: 27 November, 2012
Cross-linked functional polymers (CFPs) based on 4-vinylpyridine (4VP) have been widely used as supports for adsorbents, metal catalysts, biomedical applications, etc. For example, quaternized poly(4-vinylpyridine-co-divinylbenzene) (P4VPD, Reillex ${ }^{\mathrm{TM}} \mathrm{HPQ}$ ) has been used for uranium sorption from acidic sulfate solution [4], hexavalent chromium removal from aqueous solutions [5] and perrhenate sorption from the acidic solutions [6]. Poly(acrylamide) grafted onto crosslinked P4VPD (Reillex 425) and quaternized with potassium chloroacetate has been used for removal of mercury from aqueous solutions [7]. Also, iodomethylated P4VPD are considered as promising polymer-supported catalysts [8].

In general, CFPs can be obtained in two ways: by treating the pre-synthesized polymer with an appropriate reagent to introduce desired moieties or by polymerization of a monomer which already carries the required functional group. The former route predominates in practice, i.e., the pre-synthesized copolymers are functionalized prior to application. However, additional functionalization of porous copolymers is not always recommended. Some problems can arise, such as undesired side reactions, changes of pore structure as the consequence of chemical modification, etc. Also, the introduction of very selective, but bulky ligands can have a negative effect on selectivity and metal uptake capacity of a chelating polymer [9].

To the best of our knowledge, only few papers regarding application of porous 4VP based copolymers not additionally reacted to introduce functionalities other than pyridine nitrogen evidence their effecti- 
veness. For example, REILLEX-425 (P4VPD) supported catalyst with $\mathrm{Co}(\mathrm{II})$ and $\mathrm{Cr}(\mathrm{VI})$ ions was successfully applied in aerobic liquid/phase partial oxidation of cyclohexane [10] as well as for deperoxidation of cyclohexyl hydroperoxide under mild conditions [11].

Also, macroporous crosslinked 4VP and ethylene glycol dimethacrylate copolymer, (P4VPE) synthesized in the presence of the inert component consisting of cyclohexanol and $n$-alkanes was used successfully for heavy metal ions sorption from aqueous solutions [12].

In this study, four kinetic models (chemical reaction- and diffusion-based) were used for correlating the kinetic data of $\mathrm{Cu}(\mathrm{II}), \mathrm{Co}(\mathrm{II})$ and $\mathrm{Cr}(\mathrm{VI})$ uptake by commercial macroporous REILLEX-425, P4VPD, from aqueous solutions.

\section{EXPERIMENTAL}

\section{Analysis and spectroscopy}

Macroporous P4VPD (REILLEX-425), produced by Reilly Tarr \& Chemical Corporation was used as received in sorption experiments. All other reagents and solvents were purchased from commercial sources and used as supplied. Copper(II), cobalt(II) and chromium(VI) solutions were prepared from reagent grade copper chloride (Kemika), cobalt chloride (Carlo Erba) and potassium dichromate salt (Sigma-Aldrich), respectively, using deionized water.

The copolymer samples were analyzed for their carbon, hydrogen and nitrogen content using the Vario EL III device ( $\mathrm{GmbH}$ Hanau Instruments, Germany). Elemental analysis was calculated from multiple determinations with $\pm 0.2 \%$ agreement. The IR spectra were recorded in $\mathrm{KBr}$ pellets on a Perkin-Elmer FT-IR 1725X spectrophotometer $\left(4000-400 \mathrm{~cm}^{-1}\right)$ with DGTS detector and IRDM software. The concentration of metal ions was measured by flame atomic absorption spectrometry (FAAS, SpektrAA Varian Instruments).

The pore size distribution of P4VPD was determined by mercury porosimetry using a Carlo Erba Model 2000 instrument, operating in the interval of 0.1-200 MPa. Sample preparation was performed at room temperature and pressure of $0.5 \mathrm{kPa}$. Nitrogen adsorption-desorption isotherms were determined on Sorptomatic 1990 Thermo Finnigan automatic system using nitrogen physisorption at $77 \mathrm{~K}$. Before measurement, samples were outgassed at $403 \mathrm{~K}$ for $10 \mathrm{~h}$.

\section{Batch metal-uptake experiments}

The sorption of $\mathrm{Cu}(\mathrm{II}), \mathrm{Co}(\mathrm{II})$ and $\mathrm{Cr}(\mathrm{VI})$ ions from aqueous solutions (initial metal concentrations $0.05 \mathrm{M}$ ) was investigated in batch experiments under noncompetitive conditions, at room temperature (298 K). P4VPD (2.0 g) was soaked in $5 \mathrm{~cm}^{3}$ of buffer solution (NaOAc/HOAc, pH 5.5) for $1 \mathrm{~h}$. After that, the copo- lymer was contacted with $72.5 \mathrm{~cm}^{3}$ of metal salt solution $(0.05 \mathrm{M})$ and $72.5 \mathrm{~cm}^{3}$ of buffer solution. At appropriate times in each experiment, $0.5 \mathrm{~cm}^{3}$ aliquots were removed, diluted to $50 \mathrm{~cm}^{3}$ and used for metal concentration measurements. The reproducibility of the sorption experiments results was verified in triplicate. Standard statistical methods were used to determine the mean values and standard deviations for each set of data.

The amount of metal ions sorbed onto unit mass of macroporous copolymer beads (sorption capacity, $\mathrm{mmol} \mathrm{g}^{-1}$ ) was calculated by using the following expression:

$Q=\frac{\left(C_{0}-C\right) \times V}{m}$

where $C_{0}$ and $C$ are the concentrations of the metal ions in the initial solution and in the aqueous phase after treatment for certain period of time, respectively (in $\mathrm{mmol} \mathrm{cm}$ ), $V$ is the volume of the aqueous phase $\left(\mathrm{cm}^{3}\right)$ and $m$ is the amount of the copolymer beads used for the experiment $(\mathrm{g})$.

\section{RESULTS AND DISCUSSION}

\section{Characterization of P4VPD beads}

The commercial macroporous poly(4-vinylpyridine-co-divinylbenzene), REILLEX-425 (P4VPD), is declared by the manufacturer as 4-vinylpyridine crosslinked with ca. $25 \%$ DVB and particle size of $c a .60$ mesh $(60$ mesh equates to $250 \mu \mathrm{m}$ ). The assumed structural formula representation of P4VPD is given in Scheme 1.

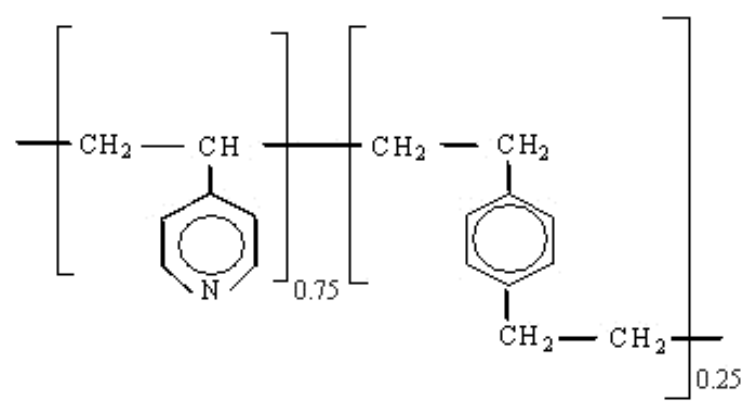

Scheme 1. Structure of commercial macroporous P4VPD.

The elemental analysis of P4VPD yields: $78.58 \% \mathrm{C}$, $7.65 \% \mathrm{H}$, and $8.77 \% \mathrm{~N}$. From these data, pyridine group concentration of $6.27 \mathrm{mmol} \mathrm{g}^{-1}$ was calculated.

The structure and composition of Reillex 425 (as supplied by the manufacturer) was further verified by FTIR spectroscopy. The characteristic $\mathrm{C}=\mathrm{C}$ and $\mathrm{C}=\mathrm{N}$ vibrations of pyridine ring give rise to the absorption bands at 1600, 1557, 1492 and $1417 \mathrm{~cm}^{-1}$ (Figure 1) $[13,14]$. The band at $3024 \mathrm{~cm}^{-1}$ is assigned to the $\mathrm{C}=\mathrm{H}$ group vibration in the aromatic ring. The absorption 


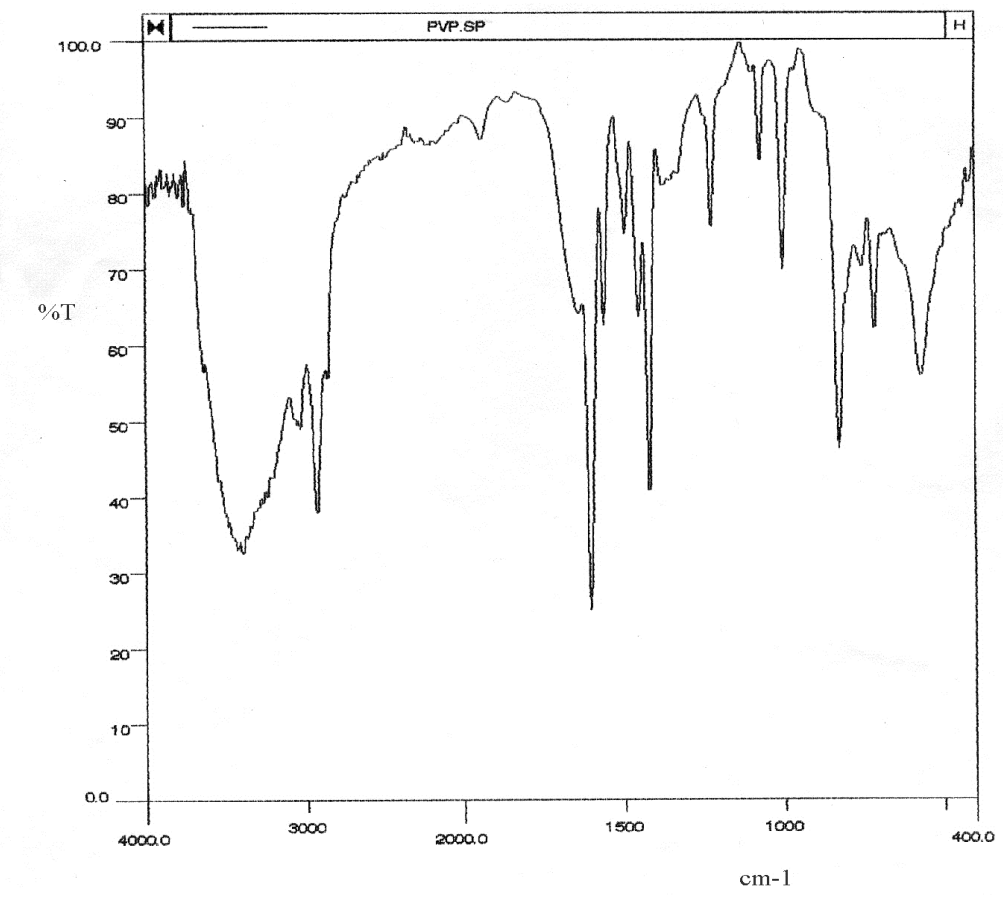

Figure 1. FTIR Spectrum of P4VPD.

bands at 1070 and $100 \mathrm{~cm}^{-1}$ correspond to to the inplane and out-of-plane rings $\mathrm{C}-\mathrm{H}$ bending, respectively [13]. The presence of the vibration at $823 \mathrm{~cm}^{-1}$ in the spectrum is attributed to disubstituted aromatic rings of the copolymer. The adsorption bands at 2924 and $1450 \mathrm{~cm}^{-1}$ are assigned to the $\mathrm{CH}_{2}$ of the ethyl group or aliphatic chain [14].

Two complementary methods were used for a proper evaluation of porous structure of P4VPD beads, mercury porosimetry and determination of nitrogen adsorption-desorption isotherms. The first one enables the detection of porous structure from macropores down to larger mesopores, while physisorption of nitrogen provides the most reliable results for pores in the micro- and mesopore regions [15].

Cumulative pore volume, $V_{\text {cum }}$, and pore diameter which corresponds to half of the pore volume, $d_{V / 2}$, of P4VPD were calculated from the cumulative pore volume distribution curves while specific surface area, $S_{\mathrm{Hg}}$, calculation was based on cylindrical pore model as described in literature $[15,16]$. Specific surface area, $S_{\mathrm{BET}}$, of P4VPD was calculated by using the BET (Brunauer, Emmett and Teller) Equation [17]. The micropores, $V_{\text {micro }}$ were analyzed using the Dubinin-Radushkevich Method [18]. Pore diameter distribution curves in mesopore region were obtained according to the Barrett, Joyner, Halenda (BJH) Method [19]. Mean pore diameter, $d_{\mathrm{BJH}}$, was derived from the pore diameter distribution curve. The value of mesopore volume, $V_{\text {meso }}$, obtained from nitrogen adsorption-desorption isotherms and calculated using the BJH method is lower than $V_{\text {cum }}$ obtained from mercury porosimetry data. The relevant porosity parameters of P4VPD used in sorption tests, obtained by nitrogen physisorption and mercury porosimetry measurements are collected in Table 1.

Table 1. Relevant P4VPD porosity parameters

\begin{tabular}{lc}
\hline$S_{\mathrm{Hg}} / \mathrm{m}^{2} \mathrm{~g}^{-1}$ & 60 \\
$d_{V / 2} / \mathrm{nm}$ & 80 \\
$S_{\mathrm{BET}} / \mathrm{m}^{2} \mathrm{~g}^{-1}$ & $52[11]$ \\
$V_{\text {micro }} / \mathrm{cm}^{3} \mathrm{~g}^{-1}$ & $0.022[11]$ \\
$V_{\text {meso }} / \mathrm{cm}^{3} \mathrm{~g}^{-1}$ & $0.159[11]$ \\
$V_{\text {cum }} / \mathrm{cm}^{3} \mathrm{~g}^{-1}$ & $0.748[11]$ \\
Mean pore diameter, $\mathrm{nm}$ & $77[11]$ \\
\hline
\end{tabular}

\section{Sorption kinetics}

From the standpoint of potential application, one of the most important properties of the chelating polymers is the rate at which sorption reaches equilibrium. Rapid sorption of metal ions is advantageous, providing a short residence time required for the completion of the actual process.

The $\mathrm{pH}$ value of 5.5 was selected for the sorption experiments as close to neutral as possible, having in mind that at $\mathrm{pH}$ values higher than 6 , significant hydrolysis of $\mathrm{Co}$ (II) and $\mathrm{Cu}$ (II) occurs at high concentrations of the order of magnitude used in this study (0.05 M) [20-22]. Thus precipitation of poorly soluble species occurs and a decline in $\mathrm{Co}(\mathrm{II})$ and $\mathrm{Cu}(\mathrm{II})$ supernatant con- 
centrations cannot be ascribed to adsorptive removal by P4VPD.

The amount of $\mathrm{Co}^{2+}$ sorbed by P4VPD rapidly increases with time reaching high maximal capacity already after $30 \mathrm{~min}$ (Figure 2). The uptake of $\mathrm{Cu}(\mathrm{II})$ and $\mathrm{Cr}(\mathrm{VI})$ is considerably lower, suggesting higher affinity of P4VPD towards $\mathrm{Co}^{2+}$ at given $\mathrm{pH}$.

The sorption of Co(II) on P4VPD was found to be very fast. After $5 \mathrm{~min}$, the amount of sorbed $\mathrm{Co}(\mathrm{II})$ ions was $90 \%$, while after 30 min $97 \%$ was sorbed. The $\mathrm{Cu}$ (II) and $\mathrm{Cr}(\mathrm{VI})$ maximal sorption capacities were considerably lower in comparison with $\mathrm{Co}(\mathrm{II})$. The sorption half time, $t_{1 / 2}$, defined as the time required to reach $50 \%$ of the total sorption capacity, for all metals was below 10 $\min$ (Table 2).

$\mathrm{pH}$ of the aqueous solution affects the surface charge of the adsorbent as well as metal speciation [23]. In the $\mathrm{pH}$ range 2.0-6.0 different forms of chromium ions such as dichromate $\left(\mathrm{Cr}_{2} \mathrm{O}_{7}{ }^{2-}\right)$, hydrochromate $\left(\mathrm{HCrO}_{4}{ }^{-}\right)$, and polychromates $\left(\mathrm{Cr}_{3} \mathrm{O}_{10}{ }^{2-}, \mathrm{Cr}_{4} \mathrm{O}_{13}{ }^{2-}\right)$ coexist, of which $\mathrm{HCrO}_{4}{ }^{-}$predominates [24]. The dichromate ion $\left(\mathrm{Cr}_{2} \mathrm{O}_{7}{ }^{2-}\right)$ is the dimmer of $\mathrm{HCrO}_{4}^{-}$which is formed when the concentration of chromium exceeds $\sim 1 \mathrm{~g} \mathrm{dm}^{-3}$, applicable here.

Pyridine nitrogen is not protonated to a significant extent at the $\mathrm{pH}$ of the experiment $\left(\mathrm{p} K_{\mathrm{a}}=5.25\right.$ [25]) and the only possible interaction with the resin is hyd- rogen bonding. Therein lies the explanation for such low sorption capacity of P4VPD for $\mathrm{Cr}(\mathrm{VI})$. It can be presumed that $\mathrm{Cr}(\mathrm{VI})$ sorption would be enhanced at low $\mathrm{pH}$. Lončarević et al. [11] have shown that $\mathrm{Cr}(\mathrm{VI})$ attaches to pyridine nitrogen of P4VPD in the form of dichromate anion.

On the other hand, positively charged $\mathrm{Co}(\mathrm{II})$ and $\mathrm{Cu}$ (II) cations form coordination complexes with the nitrogen atom of the pyridine group as was demonstrated in some previous studies of poly(4-vinylpyridine-co-divinylbenzene) $[11,13]$. The evident disparity in $\mathrm{Co}(\mathrm{II})$ and $\mathrm{Cu}$ (II) cations behavior stems most probably from the differing nature of these cations and their affinity for pyridine nitrogen (borderline Lewis base): while $\mathrm{Cu}(\mathrm{II})$ is classified as a soft Lewis acid, Co(II) falls under the borderline category and consequently the sorption capacity of P4VPD for the latter cation is high $[26,27]$.

The $t_{1 / 2}$ values obtained for P4VPD are comparable with literature data. Sugii et al. found the $t_{1 / 2}$ values for $\mathrm{Cu}(\mathrm{II})$ and $\mathrm{Ni}(\mathrm{II})$ sorption on P4VPD to be 3 and $5 \mathrm{~min}$, respectively [28]. Also, they found higher $\mathrm{Cu}(\mathrm{II})$ sorption rates for P4VPE than for P4VPD in acetate buffer [29]. The $t_{1 / 2}$ values for $\mathrm{Hg}$ (II) sorption on P4VPD quaternized with 2-chloroacetamide were 4 and $14 \mathrm{~min}$ from diluted mercury acetate and mercury chloride solutions, respectively [30].

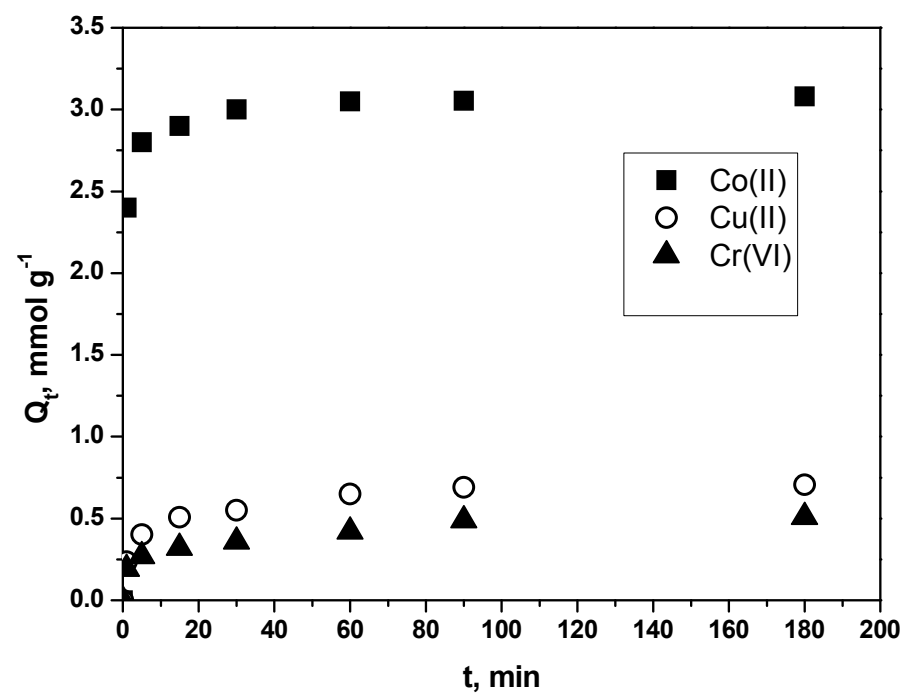

Figure 2. Sorption of $\mathrm{Cu}(\mathrm{II}), \mathrm{Co}(\mathrm{II})$ and $\mathrm{Cr}(\mathrm{VI})$ ions versus time, on P4VPD (metal ions initial concentration $0.05 \mathrm{M}, \mathrm{pH} 5.5$ ).

Table 2. Sorption capacities after $5 \mathrm{~min}, Q_{5}$, and $30 \mathrm{~min}, Q_{30}$, maximum sorption capacities, $Q_{\max }$, and the sorption half time, $t_{1 / 2}$, for heavy metal sorption on P4VPD

\begin{tabular}{|c|c|c|c|c|c|c|c|}
\hline \multirow{2}{*}{ Metal } & \multicolumn{2}{|c|}{$Q_{5}$} & \multicolumn{2}{|c|}{$Q_{30}$} & \multicolumn{2}{|c|}{$Q_{\max }$} & \multirow{2}{*}{$t_{1 / 2} / \min$} \\
\hline & $\mathrm{mmol} \mathrm{g}^{-1}$ & $\mathrm{mg} \mathrm{g}^{-1}$ & $\mathrm{mmol} \mathrm{g}^{-1}$ & $\mathrm{mg} \mathrm{g}^{-1}$ & $\mathrm{mmol} \mathrm{g}^{-1}$ & $\mathrm{mg} \mathrm{g}^{-1}$ & \\
\hline $\mathrm{Co}(\mathrm{II})$ & 2.80 & 165 & 3.00 & 177 & 3.08 & 181 & 1.5 \\
\hline $\mathrm{Cu}(\mathrm{II})$ & 0.39 & 24.8 & 0.54 & 34.3 & 0.72 & 45.7 & 6 \\
\hline $\mathrm{Cr}(\mathrm{VI})$ & 0.27 & 14.0 & 0.33 & 17.2 & 0.49 & 25.5 & 5 \\
\hline
\end{tabular}




\section{Kinetic modeling}

Sorption mechanisms depend on the sorbate-sorbent interactions and the system conditions, making it impossible to classify sorption mechanisms by solute type [3]. A logical classification based on kinetic models was introduced and widely accepted. In order to examine the controlling mechanism of heavy metals sorption processes by P4VPD, such as mass transfer and chemisorption, several equations (the pseudo-first, the pseudo-second order, intraparticle diffusion and Boyd model) were tested to interpret the experimental data.

\section{Pseudo-first and pseudo-second order equations}

Probably the earliest known and one of the most widely used kinetic equations so far for the sorption of a solute from a liquid solution is Lagergren's Equation or the pseudo-first order equation [31]:

$$
\log \left(Q_{e}-Q_{t}\right)=\log Q_{e}-\frac{\left(k_{1} t\right)}{2.303}
$$

where $k_{1}$ is the rate constant of pseudo-first-order sorption $\left(\min ^{-1}\right), Q_{e}$ and $Q_{t}$ denote the amounts of sorbed metal ions at equilibrium and at time $t\left(\mathrm{mmol} \mathrm{g}^{-1}\right)$, respectively. A plot of $\log \left(Q_{e}-Q_{t}\right)$ versus $t$ should give a straight line to confirm the applicability of the kinetic model. In a true first-order process, $\log \left(Q_{e}\right)$ should be equal to the intercept of a plot $\log \left(Q_{e}-Q_{t}\right)$ against $t$.

The pseudo-second-order rate expression is used to describe chemisorption involving valency forces through the sharing or exchange of electrons between the adsorbent and adsorbate as covalent forces, and ion exchange [32]. A pseudo-second order equation is applied in the given form [1]:

$$
\frac{t}{Q_{t}}=\frac{1}{k_{2} Q_{e}^{2}}+\frac{1}{Q_{e}} t
$$

where $k_{2}\left(\mathrm{~g}^{-1} \mathrm{mmol}^{-1} \mathrm{~min}^{-1}\right)$ is the rate constant of the pseudo-second order sorption. A plot of $t / Q_{t}$ versus $t$ should give a linear relationship for second-order kinetics.

Additionally, the initial adsorption rate $h\left(\mathrm{mmol} \mathrm{g}^{-1}\right.$ $\min ^{-1}$ ) can be determined using the Eq. [1]:

$$
h=k_{2} Q_{e}^{2}
$$

The pseudo-second-order equation has the following advantages: it does not have the problem of assigning an effective adsorption capacity, i.e., the adsorption capacity, the rate constant of pseudo-secondorder, and the initial adsorption rate all can be determined from the equation without knowing any parameter beforehand [1].

The rate constants $k_{1}, k_{2}$ and $h$, equilibrium sorption capacity, $Q_{e}$, and the coefficients of determination, $R^{2}$, calculated from the values of intercepts and slopes of corresponding plots for the pseudo-first and the pseudo-second order equations are given in Table 3. Plots of $\log \left(Q_{e}-Q_{t}\right)$ vs. $t$ (pseudo-first order) and $t / Q_{t}$ vs. $t$ (pseudo-second order) for heavy metals sorption by P4VPD are shown in Figure 3.

Table 3. Kinetic parameters for Co(II), CU(II) and Cr(VI) uptake using P4VPD as sorbent

\begin{tabular}{lccc}
\hline \multirow{2}{*}{ Parameter } & \multicolumn{3}{c}{ Sorbate } \\
\cline { 2 - 4 } & Co & $\mathrm{Cu}$ & $\mathrm{Cr}$ \\
\hline$Q_{\mathrm{e}} / \mathrm{mmol} \mathrm{g}^{-1}$ & 3.08 & 0.71 & 0.51 \\
\hline \multicolumn{4}{c}{ Pseudo-first order } \\
\hline$k_{1} / \mathrm{min}^{-1}$ & 0.043 & 0.037 & 0.030 \\
$Q_{\mathrm{e}}{ }^{\text {calc }} / \mathrm{mmol} \mathrm{g}^{-1}$ & 0.62 & 0.47 & 0.36 \\
$R^{2}$ & 0.7428 & 0.9667 & 0.9345 \\
\hline \multicolumn{4}{c}{ Pseudo-second order } \\
\hline$k_{2} / \mathrm{g} \mathrm{mmol}^{-1} \mathrm{~min}^{-1}$ & 0.462 & 0.251 & 0.230 \\
$h, / \mathrm{mmol} \mathrm{g}^{-1} \mathrm{~min}^{-1}$ & 4.409 & 0.1319 & 0.06381 \\
$Q_{\mathrm{e}}$ calc $^{2} \mathrm{mmol} \mathrm{g}^{-1}$ & 3.09 & 0.726 & 0.526 \\
$R^{2}$ & 0.9999 & 0.9985 & 0.9941 \\
\hline \multicolumn{5}{c}{ Intraparticle } \\
\hline$k_{\text {id }} / \mathrm{mmol} \mathrm{g}^{-1} \mathrm{~min}^{-0.5}$ & 0.0459 & 0.0432 & 0.0271 \\
$C_{\text {id }} / \mathrm{mmol} \mathrm{g}^{-1}$ & 2.71 & 0.318 & 0.211 \\
$R^{2}$ & 0.9481 & 0.9793 & 0.9980 \\
\hline
\end{tabular}

The theoretical $Q_{e}$ values estimated from the firstorder kinetic model were not in accordance with the experimental ones, and the coefficients of determination were found to be rather low. This indicates that the first-order kinetic model is not applicable to the $\mathrm{Co}(\mathrm{II}), \mathrm{Cu}(\mathrm{II})$ and $\mathrm{Cr}(\mathrm{VI})$ sorption on P4VPD. On the other hand, the theoretical $Q_{e}$ values calculated from pseudosecond order model were found to be very close to the experimental values of equilibrium sorption, $Q_{e}$, with coefficients of determination higher than 0.99. The initial sorption rate, $h$, is the highest for $\mathrm{Co}(\mathrm{II})$ and the lowest for $\operatorname{Cr}(\mathrm{VI})$, which reflects the affinity of the sorbent for these sorbate species.

The superior fit of the pseudo-second-order model with experimental data implies that the adsorption process may be interaction controlled, with chemisorption involving valence force through sharing or exchange of electrons between P4VPD and heavy metal ions [33]. Plazinski et al., however, showed convincing proof that the pseudo-second order equation is able to represent the kinetics of sorption in the systems for which not only the rate of surface reaction governs the overall process rate [2]. Further on, Plazinski et al. drew a general conclusion that the expressions of the pseudo-first order and the pseudo-second order model did not correspond to only one kinetic model, but they presented more or less flexible mathematical formulae, able to simulate adequately well the behavior characte- 


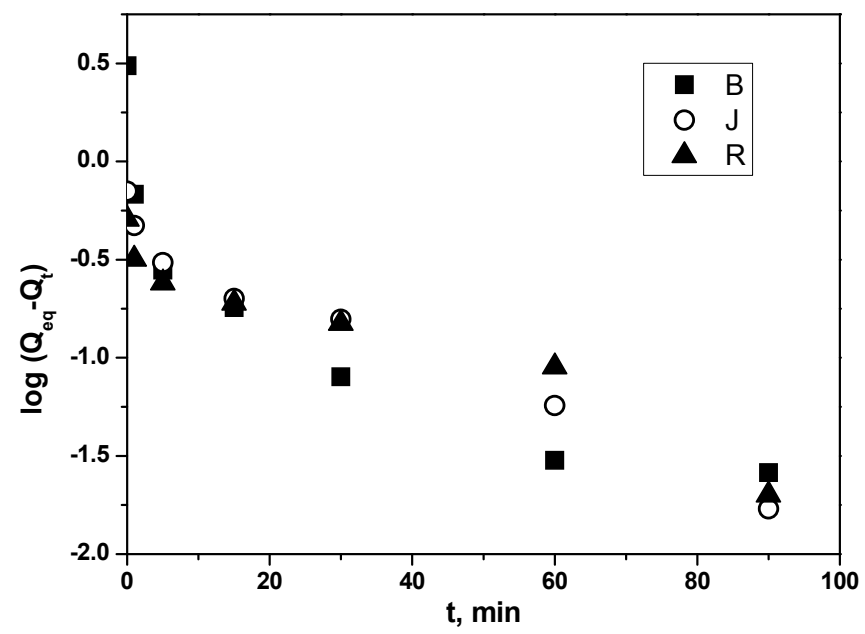

(a)

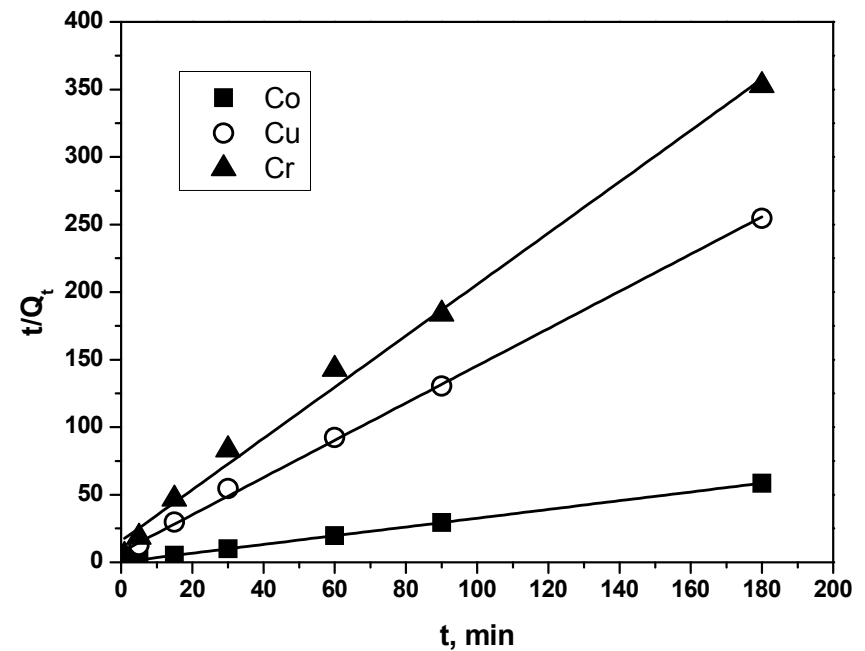

(b)

Figure 3. Pseudo-first (a) and pseudo-second order kinetics (b) of the heavy metals uptake by P4VPD at $25{ }^{\circ} \mathrm{C}$.

ristic of physical kinetic processes of various kinds (i.e., surface reaction and intraparticle diffusion) [2].

\section{Diffusion-based kinetic modeling}

Generally, if the investigated sorption process involves metal species and porous sorbent, it is a multistep process, including [34]: i) bulk diffusion, ii) external mass transfer of sorbate molecules across the liquid film around the sorbent particles, iii) binding of sorbate molecules on the active sites distributed on the outer surface of the sorbent particles, iv) intraparticle diffusion of sorbate molecules into macro-, meso- and micropores, and $v$ ) sorption of sorbate molecules onto active sites distributed within the sorbent particles. The steps $i i i$ and $v$ are usually very fast and hence they do not have a determinant role in governing sorption rates. Any of the four previous steps may be the rate controlling factor or any combination of the steps [3]. The entire sorption process is thus affected by changes to any step, and these steps can be affected by many experimental conditions, including particle size, agitation rate and $\mathrm{pH}$, among others [3]. Thus, external mass transfer and intraparticle diffusion warrant further consideration.

Since the pseudo-first and the pseudo-second order kinetic models cannot identify the influence of diffusion on sorption, the Weber and Morris equation was used for calculation of the rate constants of intraparticle diffusion [35]. The intraparticle diffusion model presumes that film diffusion or boundary layer diffusion is negligible, and that intraparticle diffusion is the only ratecontrolling step.

The rate of intraparticle diffusion can be calculated according to the equation [36]:

$Q_{t}=C_{\mathrm{id}}+k_{\mathrm{id}} t^{0.5}$ 
where $k_{\text {id }}$ is the intraparticle diffusion rate constant ( $\left.\mathrm{mmol} \mathrm{g}^{-1} \mathrm{~min}^{-0.5}\right)$, and $C_{\text {id }}$ is the intercept which is proportional to the boundary layer thickness $\left(\mathrm{mmol} \mathrm{g}^{-1}\right.$ ) [37].

The rate constant of intraparticle transport, $k_{\text {id }}$, is estimated from the slope of the linear portion of the plot of amount sorbed against square root of time. In the case of a linear plot of $Q_{t}$ versus $t^{0.5}$, and if the line passes through the origin, intraparticle diffusion is the only rate-controlling step [38]. If not, some other mechanisms are also involved.

For investigated metal ions sorption by porous P4VPD, the plots $Q_{t}$ versus $t^{1 / 2}$ did not pass through the origin (Figure 4) suggesting that even though the adsorption process involved intraparticle diffusion, it was not the only rate-controlling step. The positive value of intercept $C_{\text {id }}$ is indicative of some degree of boundary layer control [38].

The multilinear shape of $Q_{t}-t^{1 / 2}$ relationships indicates that more than one process affects $\mathrm{Cr}(\mathrm{VI})$ adsorption. As can be seen from Figure 5, plot $Q_{t}$ versus $t^{1 / 2}$ for Co(II) has first sharper portion, which can be considered as an external surface adsorption or faster adsorption stage, followed by gradual adsorption where intraparticle diffusion is rate controlled. After that, in the final equilibrium stage the intraparticle diffusion starts to slow down due to the low adsorbate concentration in solution. Kumar et al. observed the similar for $\mathrm{Cr}$ (III) removal by using an amine-based polymer, aniline-formaldehyde condensate (AFC) coated on silica gel [39].

The rate of uptake is limited by the size of adsorbate molecule, the adsorbate concentration and its affinity towards the adsorbent, the diffusion coefficient of the adsorbate in the bulk, the adsorbent pore size distribution and the degree of mixing step [38]. In this case, it is apparent from Table 3 . that the size of the metal species and their affinity towards P4VPD are crucial for the observed trend in the $k_{\text {id }}$ values. Intraparticle diffusion is facilitated by the presence of macroporosity.

The dependence of the amount adsorbed on the square-root of time has a concave character for the two polymers. A model investigation by Rudzinski et al. has shown that such curve shape may be due to a combined effect of the rate of surface reaction and that of the solute transport from the bulk to the surface [2], in support of deductions made in the case of this sorbate-sorbent system.

The contribution of boundary layer or film diffusion indicated by non-zero values of the intraparticle plot intercept is often confirmed using the model given by Boyd [36]:

$$
\begin{aligned}
& F=1-\frac{6}{\pi^{2}} \sum_{n=1}^{\infty} \frac{1}{n^{2}} \exp \left(-\frac{n^{2} \pi^{2} D_{i} t}{r^{2}}\right) \\
& F=1-\frac{6}{\pi^{2}} \sum_{n=1}^{\infty} \frac{1}{n^{2}} \exp \left(-n^{2} B t\right)
\end{aligned}
$$

where $F$ is the fractional attainment of equilibrium at time $t$ ( $\mathrm{min}$ ) obtained from the expression:

$$
F=\frac{Q_{t}}{Q_{e}}
$$

and

$$
B=\frac{D_{i} \pi^{2}}{r^{2}}
$$

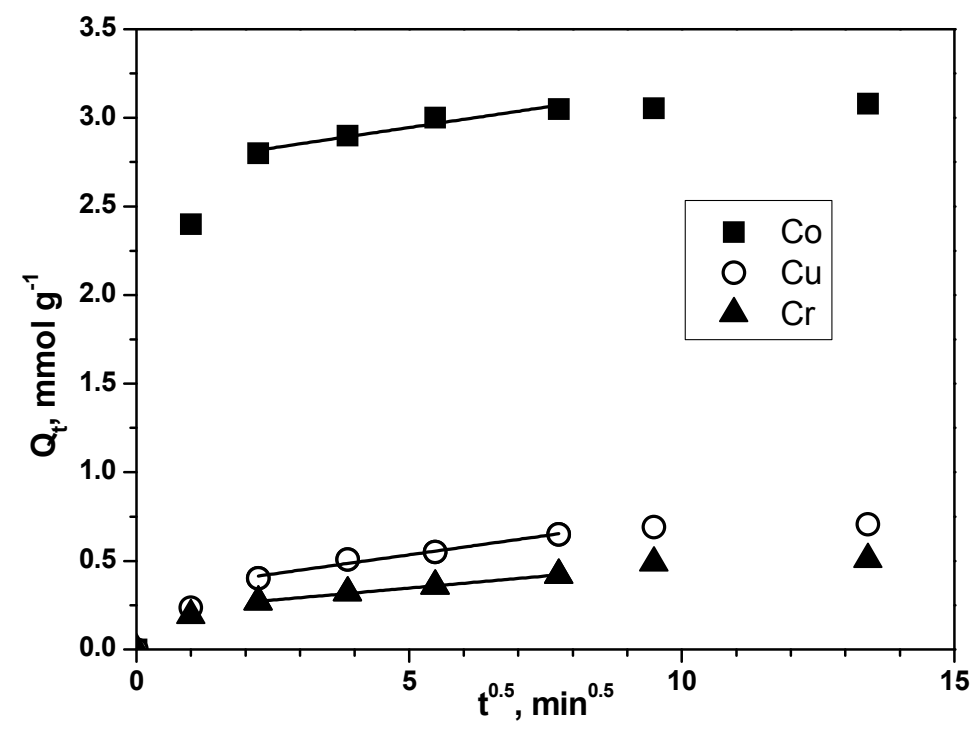

Figure 4. Intraparticle diffusion plots for $\mathrm{CU}(\mathrm{II}), \mathrm{Co}(\mathrm{II})$ and $\mathrm{Cr}(\mathrm{VI})$ uptake using P4VPD as sorbent. 


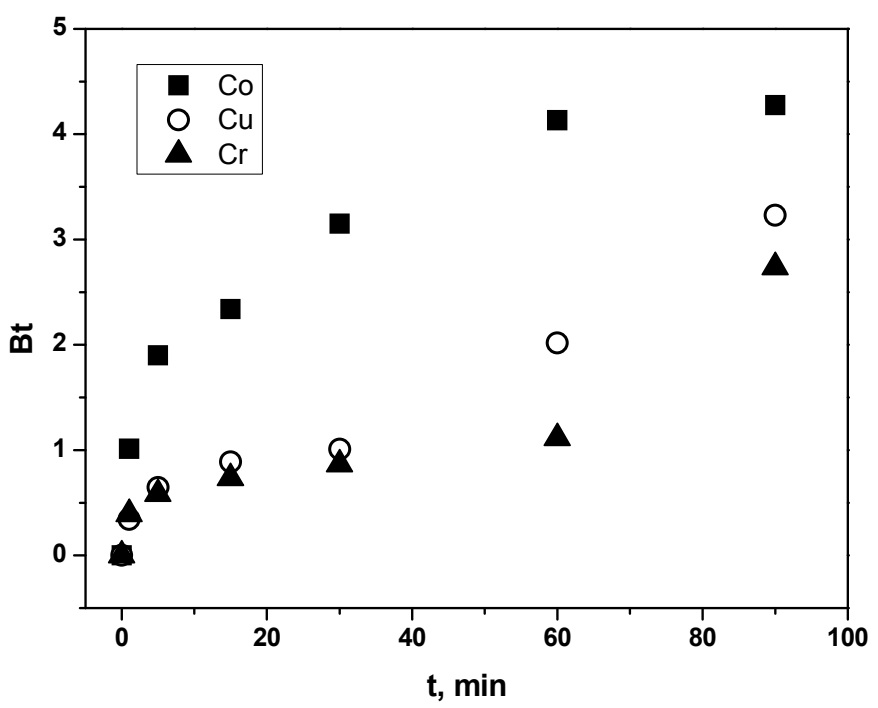

Figure 5. The Boyd plots for sorption of $\mathrm{Cu}(I I), \mathrm{Co}(I I)$ and $\mathrm{Cr}(\mathrm{VI})$ using P4VPD as sorbent.

where $B$ is the time constant $\left(\mathrm{min}^{-1}\right), D_{i}$ is the effective diffusion coefficient of the metal ions in the sorbent phase $\left(\mathrm{cm}^{2} \mathrm{~min}^{-1}\right), r$ is the radius of the sorbent particle $(\mathrm{cm})$, assumed to be spherical, $n$ is an integer that defines the infinite series solution. The approximations for Bt proposed by Reichenberg [40] are as follows:

$F$ values $<0.85, B t=\left(\pi^{\frac{1}{2}}-\left(\pi-\frac{\pi^{2} F}{3}\right)^{\frac{1}{2}}\right)$

$F$ values $>0.85, B t=-0.4997-\ln (1-F)$

Thus, the value of $B t$ can be computed for each value of $F$, and then plotted against time. The linearity of these so-called Boyd Plots (Figure 5) was employed to distinguish between sorption controlled by film diffusion and particle diffusion [20]. If the plot is in the form of straight line passing through the origin, this indicates that sorption processes are governed by particle-diffusion mechanisms; otherwise, they are controlled by film diffusion [41]. From Figure 5, it was observed that the plots were neither linear nor passed through the origin for $\mathrm{Co}(\mathrm{II}), \mathrm{Cu}(\mathrm{II})$ and $\mathrm{Cr}(\mathrm{VI})$ indicating the film diffusion-controlled mechanism.

The strong external resistance which hinder the external mass transfer and is rate-limiting during the initial stages of sorption (0-5 min as seen in Figure 5) may be mainly due to the the absence of mixing and high affinity of adsorbate to adsorbent [42]. The intraparticle step limits the overall transfer in the sorption period of 5-60 min since the investigated systems have high concentrations of adsorbate and relatively large particle size of adsorbent.

In order to make distinction between kinetic and diffusion control, a very general guideline can be used: if equilibrium is achieved within $3 \mathrm{~h}$, the process is usually kinetic controlled and above $24 \mathrm{~h}$, it is diffusion controlled [3]. Either or both kinetic and sorption processes may be rate controlling in the 3 to $24 \mathrm{~h}$ period, such as in the case of $\mathrm{Cu}(\mathrm{II}), \mathrm{Co}(\mathrm{II})$ and $\mathrm{Cr}(\mathrm{VI})$ sorption by commercial macroporous REILLEX-425, P4VPD.

\section{CONCLUSION}

Commercial macroporous crosslinked poly(4-VP-co-DVB), P4VPD (REILLEX 425), was used as heavy metal ions sorbent from aqueous solutions without additional functionalization.

In this manner, some problems, such as the undesired side reactions and the change of pore structure as a consequence of chemical modification, are avoided, simplifying the process and reducing the costs as well. Kinetics of $\mathrm{Co}(\mathrm{II}), \mathrm{Cu}(\mathrm{II})$ and $\mathrm{Cr}(\mathrm{VI})$ removal from aqueous solutions was tested in batch, under non-competitive conditions at room temperature and analyzed using pseudo-first order, pseudo-second order, intraparticle diffusion and Boyd's Model. The very high maximum Co(II) capacity of $181 \mathrm{mg} \mathrm{g}^{-1}$ of P4VPD was observed. Kinetic studies showed that the adsorption adhered to the pseudo-second-order model since theoretical and experimental sorption capacities were in excellent agreement, with $R^{2} \geq 0.99$. The intraparticle diffusion model revealed that pore diffusion was not the only rate-controlling step and indicated some degree of boundary layer control in the process of heavy metal sorption by the porous copolymer. Boyd plots showed that film diffusion mechanism may be involved in the process of $\mathrm{Co}(\mathrm{II}), \mathrm{Cu}(\mathrm{II})$ and $\mathrm{Cr}(\mathrm{VI})$ sorption by P4VPD. 


\section{Acknowledgements}

This work was supported by the Ministry of Education, Science and Technological Development of the Republic of Serbia (Project III 43009).

\section{REFERENCES}

[1] Y.S. Ho, Review of second-order models for adsorption systems, J. Hazard. Mater. 136 (2006) 681-689.

[2] W. Plazinski, W. Rudzinski, A. Plazinska, Theoretical models of sorption kinetics including a surface reaction mechanism: A review, Adv. Colloid. Interface Sci. 152 (2009) 2-13.

[3] Y.S. Ho, J.C. Y. Ng, G. McKay, Kinetics of pollutant sorption by biosorbents: Review, Sep. Purif. Method. 29 (2000) 189-232.

[4] M. Chanda, G. Rempel, Uranium sorption behavior of a macroporous, quaternized poly(4-vinylpyridine) resin in sulfuric acid medium, React. Polym. 18 (1992) 141-154.

[5] V. Neagu, S. Mikhailovsky, Removal of hexavalent chromium by new quaternized crosslinked poly(4-vinylpyridines), J. Hazard. Mater. 183 (2010) 533-540.

[6] D. Jermakowicz-Bartkowiak, B. N. Kolarz, Poly(4-vinylpyridine) resins towards perrhenate sorption and desorption, React. Funct. Polym. 71 (2011) 95-103.

[7] E. Yavuz, B. F. Senkal, N. Bicak, Poly(acrylamide) grafts on spherical polyvinyl pyridine resin for removal of mercury from aqueous solutions, React. Funct. Polym. 65 (2005) 121-125.

[8] M. Giammatteo, L.Tauro, A.A. D'Archivio, L. Galantini, A. Panatta, E. Tettamanti, K. Jerabek, B. Corain, Crosslinked poly-4-vinylpyridines as useful supports in metal catalysis: micro- and nanometer scale morphology, J. Mol. Catal., A 268 (2007) 176-184.

[9] P.M. Van Berkel, S.C. Van der Slot, W.L. Driessen, J. Reedijk, D.C. Sherrington, Influence of the polymer matrix on the metal-ion uptake characteristics of ligandmodified poly(glycidyl methacrylate-co-trimethylolpropane trimethacrylate) polymers, Eur. Polym. J. 33 (1997) 303-310.

[10] D. Lončarević, Ž. Čupić, M. Odović, Inhibition Effects in the partial oxidation of cyclohexane on polymer supported Co(II) catalysts, J. Serb. Chem. Soc. 70 (2005) 209-221.

[11] D. Lončarević, J. Krstić, J. Dostanić, D. Manojlović, Ž. Čupić, D.M. Jovanović, Cyclohexane oxidation and cyclohexyl hydroperoxide decomposition by poly(4-vinylpyridine-co-divinylbenzene) supported cobalt and chromium complexes, Chem. Eng. J. 157 (2010) 181-188.

[12] A. Nastasović, D. Đorđević, D. Jakovljević, T. Novaković, Z. Vuković, S. Jovanović, Heavy metal ions removal with macroporous poly poly(4-vinyl pyridine-co-ethylene glycol dimethacrylate), in: R.K. Bregg (Ed.), Leading Edge Polymer Research, Nova Science Publishers, New York, 2006, pp. 213-234.

[13] K.H. Wu, Y.R. Wang, W.H. Hwu, FTIR and TGA studies of poly(4-vinylpyridine-co-divinylbenzene)-Cu(II) complex, Polym. Degrad. Stab. 79 (2003) 195-200.
[14] J. Ortiz-Palacios, J. Cardoso, O. Manero, Production of macroporous resins for heavy-metal removal. I. Nonfunctionalized polymers, J. Appl. Polym. Sci. 107 (2008) 2203-2210.

[15] P.A. Webb, C. Orr, Analytical Methods in Fine Particle Technology, Micromeritics Instrument Corporation, Norcross, 1997, pp. 185.

[16] S. Jovanović, A. Nastasović, N. Jovanović, K. Jeremić, Z. Savić, The influence of inert component composition on the porous structure of glycidyl methacrylate/ethylene glycol dimethacrylate copolymers, Angew. Makromol. Chem. 219 (1994) 161-168.

[17] S. Brunauer, P.H. Emmett, E. Teller, Adsorption of gases in multimolecular layers. J. Am. Chem. Soc. 60 (1938) 309-319.

[18] M.M. Dubinin, Physical adsorption of gases and vapors in micropores, in: D.A. Cahenhead (Ed.), Progress in Surface and Membrane Science, $9^{\text {th }}$ ed., Academic Press, New York, 1975, pp. 1-70.

[19] E.P. Barrett, L.G. Joyner, P.P. Halenda, The determination of pore volume and area distributions in porous substances. I. Computations from nitrogen isotherms, J. Am. Chem. Soc. 73 (1951) 373-380.

[20] R. Djeribi, O. Hamdaoui, Sorption of copper(II) from aqueous solutions by cedar sawdust and crushed brick, Desalination 225 (2008) 95-112.

[21] C.P. Huang, M.W. Tsang, Y.S. Hseigh, The removal of cobalt (II) from water by activated carbon, AIChE Symp. Ser. 243 (1985) 81 85-98.

[22] M.V. Dinu, E.S. Dragan, Heavy metals adsorption on some iminodiacetate chelating resins as a function of the adsorption parameters, React. Funct. Polym. 68 (2008) 1346-1354.

[23] S.M. Nomanbhay, K. Palanisamy, Removal of heavy metal from industrial wastewater using chitosan coated oil palm shell charcoal, Electron J. Biotechnol. 8 (2005) 43$-53$.

[24] T. Karthikeyan, S. Rajgopal, L. R. Miranda, $\mathrm{Cr}(\mathrm{VI})$ adsorption from aqueous solution by Hevea Brasilinesis sawdust activated carbon, J. Hazard. Mater. 124 (2005) 192-199.

[25] Y. Zubavichus, M. Zharnikov, Y. Yang, O. Fuchs, E. Umbach, C. Heske, A. Ulman, M. Grunze, XPS and NEXAFS study of water adsorption on the pyridine-terminated thiolate self-assembled monolayer, Langmuir 20 (2004) 11022-11029.

[26] R.G. Pearson, Hard and soft acids and bases, HSAB. Part I, J. Chem. Educ. 45 (1968) 581-587.

[27] R.G. Pearson, Hard and soft acids and bases, HSAB. Part II, J. Chem. Educ. 45 (1968) 643-648.

[28] A. Sugii, N. Ogawa, Y. linuma, H. Yamamura, Selective metal sorption on cross-linked poly(vinylpyridine) resins, Talanta 28 (1981) 551-556.

[29] A. Sugii, N. Ogawa, K. Harada, K. Nishimura, Metal sorption of macroreticular poly(4-vinylpyridine) resins crosslinked with oligo(ethylene glycol dimethacrylates), Anal. Sci. 4 (1988) 399-402. 
[30] H.B. Sonmez, N. Bicak, Quaternization of poly(4-vinyl pyridine) beads with 2-chloroacetamide for selective mercury extraction, React. Funct. Polym. 51 (2002) 55-60.

[31] A.G. Ritchie, Alternative to the Elovich equation for the kinetics of adsorption of gases on solids, J. Chem. Soc. Faraday Trans. 73 (1977) 1650-1653.

[32] Y.S. Ho, G. McKay, A comparison of chemisorption kinetic models applied to pollutant removal on various sorbents, Process Saf. Environ. Prot. (Trans. Ichem. E., Part B), 76 (1998) 332-340.

[33] H. Zhang, Y. Tang, D. Cai, X. Liu, X. Wang, Q. Huang, Z. $Y u$, Hexavalent chromium removal from aqueous solution by algal bloom residue derived activated carbon: equilibrium and kinetic studies, J. Hazard. Mater. 181 (2010) 801-808.

[34] A.E. Ofomaja, Sorptive removal of Methylene Blue from aqueous solution using palm kernel fibre: Effect of fibre dose, Biochem. Eng. J. 40 (2008) 8-18.

[35] W.J. Weber, J.C. Morris, Kinetics of adsorption on carbon from solution, J. Sanit. Eng. Div., Am. Soc. Civ. Eng. 89 (1963) 31-60.

[36] G.E. Boyd, A.M. Adamson, L.S. Myers, The exchange adsorption of ions from aqueous solutions by organic zeolites. Part II, .J. Am. Chem. Soc. 69 (1947) 2836-2848.
[37] A.M. Donia, A.A. Atia, W.A. Al-amrani, A. M. El-Nahas, Effect of structural properties of acid dyes on their adsorption behaviour from aqueous solutions by amine modified silica, J. Hazard. Mater. 161 (2009) 1544-1550.

[38] A.S. Özcan, A. Özcan, Adsorption of acid dyes from aqueous solutions onto acid-activated bentonite, J. Colloid Interface Sci. 276 (2004) 39-46.

[39] P.A. Kumar, M. Ray, S. Chakraborty, Adsorption behaviour of trivalent chromium on amine-based polymer aniline formaldehyde condensate, Chem. Eng. J. 149 (2009) 340-347.

[40] D. Reichenberg, Properties of ion-exchange resins in rela- tion to their structure III, kinetics of exchange, J. Am. Chem. Soc. 75 (1953) 589-592.

[41] D. Mohan, K.P. Singh, Single- and multi-component adsorption of cadmium and zinc using activated carbon derived from bagasse-an agricultural waste, Water Res. 36 (2002) 2304-2318.

[42] V. Vadivelan, K.V. Kumar, Equilibrium, kinetics, mechanism, and process design for the sorption of methylene blue onto rice husk, J. Colloid Interface Sci. 286 (2005) 90-100.

\section{IZVOD}

\section{KINETIČKO MODELOVANJE SORPCIJE TEŠKIH METALA KOPOLIMEROM SA OSNOVOM VINIL PIRIDINA}

Danijela D. Maksin ${ }^{1}$, Slađana O. Kljajević ${ }^{2}$, Maja B. Đolić ${ }^{1}$, Jelena P. Marković ${ }^{1}$, Bojana M. Ekmeščić ${ }^{2}$, Antonije E. Onjia ${ }^{1}$, and Aleksandra B. Nastasović ${ }^{2}$

${ }^{1}$ Univerzitet u Beogradu, Institut za nuklearne nauke „Vinča“, Beograd, Srbija

${ }^{2}$ Univerzitet u Beogradu, IHTM - Centar za hemiju, Odeljenje za polimere, Beograd, Srbija

(Naučni rad)

Komercijalni makropozni poli(4-vinilpiridin-co-divinilbenzen) [P4VPD], Reillex425, bez dodatne funkcionalizacije korišćen je za ispitivanje mogućnosti sorpcije teških metala iz vodenih rastvora. Na taj način su izbegnuti neki problemi do kojih može doći prilikom uvođenja funkcionalnih grupa selektivnih za određene jone metala u polimerne sorbente, kao što su nepoželjne sporedne reakcije i promena porozne strukture. P4VPD je okarakterisan živinom porozimetrijom, određivanjem adsorpciono-desorpcionih niskotemperaturnih izotermi azota, infracrvenom spektroskopijom (FTIR) i elementalnom analizom. U statičkim eksperimentima su određene brzine sorpcije $\mathrm{Cu}(\mathrm{II}), \mathrm{Co}(\mathrm{II})$ i $\mathrm{Cr}(\mathrm{VI})$ jona pomoću P4VPD pri nekompetitivnim uslovima i pri sobnoj temperaturi ( $298 \mathrm{~K})$. Zapažena je brza sorpcija ispitivanih jona, naročito u slučaju Co(II), pri čemu su zapažene vrednosti poluvremena sorpcije, $t_{1 / 2}$, od $1,5 \mathrm{~min}$ i visoka vrednost maksimalnog kapaciteta sorpcije, $Q_{\max }$ od $3,08 \mathrm{mmol} \mathrm{g}^{-1}$ (181 $\mathrm{mg} \mathrm{g}^{-1}$ ). Prilikom analiziranja sorpcije ispitivanih metala pomoću P4VPD korišćena su četiri kinetička modela (model pseudo-prvog i pseudo-drugog reda, model difuzije unutar čestica i Bojdov model). Pokazalo se da sorpciju jona metala najbolje opisuje model pseudo-drugog reda, pošto je za ovaj model dobijeno odlično slaganje eksperimentalnih i teorijskih vrednosti kapaciteta sorpcije, kao i vrednosti $R^{2} \geq 0,99$. Analiza eksperimentalnih rezultata pomoću modela difuzije unutar čestica pokazala je da difuzija kroz pore nije jedini stupanj koji određuje brzinu sorpcije i ukazala na delimičan uticaj graničnog sloja na sorpciju teških metala pomoću poroznog kopolimera.
Ključne reči: Poli(4-vinilpiridin-co-divinilbenzen)• Makroporozni kopolimer $\bullet$ Sorpcija $\mathrm{Cu}(\mathrm{II}), \mathrm{Co}(\mathrm{II})$ i $\mathrm{Cr}(\mathrm{VI})$ jona $\bullet$ Kinetički modeli 